\title{
Millimeter wave treatment promotes chondrocyte proliferation by upregulating the expression of cyclin-dependent kinase 2 and cyclin A
}

\author{
XIHAI LI ${ }^{1}$, MIN DU $^{2}$, XIANXIANG LIU ${ }^{1}$, WENLIE CHEN ${ }^{1}$, \\ MINGXIA WU ${ }^{1}$, JIUMAO LIN ${ }^{1}$ and GUANGWEN WU ${ }^{1}$
}

\begin{abstract}
${ }^{1}$ Fujian University of Traditional Chinese Medicine, University Town, Minhou Shangjie, 1 Huatuo Road, Fuzhou, Fujian 350108; ${ }^{2}$ Institute of Precision Instrument, Fuzhou University, Fuzhou 350002, P.R. China
\end{abstract}

Received February 9, 2010; Accepted April 8, 2010

DOI: $10.3892 /$ ijmm_00000437

\begin{abstract}
We investigated the effects of millimeter wave treatment on the expression of the cell cycle regulating proteins cyclin-dependent kinase 2 (CDK2) and cyclin A in chondrocytes. Knee articular cartilage from SD rats was used to establish cultured primary chondrocytes. After identification using toluidine blue staining, passage 2 chondrocytes were randomly divided into different groups and treated with nocodazole or millimeter wave. The RNA expression of CDK2 and cyclin A was measured using RT-PCR, and their protein levels were detected by Western blotting. Cell cycle analysis showed that nocodazole treatment significantly increased the number of $\mathrm{G} 0 / \mathrm{G} 1$ and $\mathrm{G} 2 / \mathrm{M}$ stage chondrocytes and decreased the amount of $\mathrm{S}$ phase cells. In contrast, millimeter wave treatment significantly decreased the number of G0/G1 and $\mathrm{G} 2 / \mathrm{M}$ chondrocytes and increased the number of $\mathrm{S}$ phase cells. The mRNA and protein levels of CDK2 and cyclin A consistently demonstrated a reverse trend, with the lowest levels in the chondrocytes treated with nocodazole. The expression of CDK2 and cyclin A was higher in chondrocytes receiving millimeter wave treatment than in untreated cells. In conclusion, millimeter wave treatment induces CDK2 and cyclin A expression, accelerates S-phase entry and G2/M transition and promotes chondrocyte cell cycle progression.
\end{abstract}

\section{Introduction}

The major pathological damage caused by osteoarthritis is cartilage degeneration. The balance of catabolism and anabolism within chondrocytes helps maintain the structural and functional integrity of the extracellular cartilage matrix. In the early stages of osteoarthritis development, cartilage tissue show self-repairing activity, volume of chondrocytes increases,

Correspondence to: Dr Xianxiang Liu, Fujian University of Traditional Chinese Medicine, Fuzhou 350108, P.R. China

E-mail: liuxianxiang@163.com

Key words: millimeter wave, chondrocytes, cell proliferation and the synthesis of proteoglycan accelerates. In the late stage of osteoarthritis, the balance is broken, and the damaging effect of inflammation becomes more dramatic. Chondrocytes can rapidly respond to changes in the joint microenvironment and regulate the dynamic equilibrium between the degradation and synthesis of the extracellular matrix (ECM) (1-4). Therefore, the functional changes of chondrocytes play important roles in the degeneration of the joint cartilage, and chondrocyte proliferation is one of the important factors contributing to the maintenance of the cellular function.

The cell cycle is composed of four different stages, G1, S, G2 and M phase. There are two important checkpoints regulating stage transition and cell cycle progression, the G1/S and G2/M checkpoints. Stage transitions in the cell cycle are controlled by interactions among the molecules of the cyclin-cyclin dependent kinase (CDK)-CDK inhibitor (CKI) axis. In this system, cyclins interact with CDKs to positively regulate their activity. Conversely, CKIs can competitively inhibit the cyclin-CDK interaction and thereby negatively regulate the activity of CDKs $(5,6)$. Cyclin $\mathrm{A}$ is first synthesized at the end of the G1 stage and regulated by E2F together with cyclin $\mathrm{E}$ at the transcriptional level. Cyclin A binds to CDK2 in the cell cycle and has dual functions of regulating DNA synthesis and $\mathrm{M}$ phase entry $(7,8)$. CDK2 is an important positive regulator for cell cycle progression. The level and activity of CDK2 play rate-limiting roles in cell cycle stage transitions and the G1/S and G2/M checkpoints, especially in the $\mathrm{S}$ phase progression $(9,10)$. Once the CDK2cyclin $\mathrm{E}$ complex is transported into the nucleus, it can promote cell cycle progression through the G1/S checkpoint and initiate DNA synthesis and centriole duplication. At the end of G2, CDK2 binds to cyclin A, and the CDK2-cyclin A complex promotes $\mathrm{M}$ phase entry, regulates mitosis, and enhances cell proliferation.

The millimeter wave is an electromagnetic wave with a wavelength between 1-10 mm and a frequency of 30-300 GHz. It has been shown that millimeter waves can evoke multiple biological effects, both locally and globally. Organisms produce coherent oscillation at $0.5 \times 10^{10}-3 \times 10^{12}$ during metabolism, and the frequency of a millimeter wave is in the same range. Therefore, the energy of a millimeter wave can be absorbed by the organism through resonance. In turn, the 
energy can be transferred and interfere with signal transduction within the organism and dynamically regulate metabolism (11-13). Our previous study showed that millimeter wave treatment induced the direct differentiation of mesenchymal stem cells (MSCs) to chondrocytes by upregulating the mRNAs of Cbfa1 and Sox9 and ultimately the levels of glycosaminoglycan and type II collagen. The differentiated cells can secrete chondrocyte-specific matrix, and the degree of differentiation is enhanced with increased treatment time (14). Nocodazole is a drug, like colchicines, that specifically binds to microtubules and interferes with spindle formation, thereby blocking the cell cycle at the G2/M transition (1517). To further discover the millimeter wave's mechanism of action, we used nocodazole to block the cell cycle the in vitro cultured chondrocytes and observed the effect of millimeter waves on the proliferation of these cells. Our work explored the targets of millimeter waves that regulate chondrocyte proliferation at the molecular and cellular levels.

\section{Materials and methods}

Reagents and equipment. The reagents used in this study included fetal bovine serum (FBS), Dulbecco's Modified Eagle Medium (DMEM), and trypsin from Hyclone Inc. (Carlsbad, CA, USA); MTT, type-II collagenase, and nocodazole from Sigma (NJ, USA); toluidine blue stain from Sinopharm Chemical Reagent Co. Ltd (Shanghai, China); a total protein extraction kit from Nanjing KeyGen Biotech. (Nanjing, Jiangsu, China); antibodies against CDK2, cyclin A, and ß-actin from Santa Cruz (Santa Cruz, CA, USA); HRPsecondary rabbit anti-goat antibody from Zhongshan Goldenbridge Biotech (Beijing, China); an ECL kit from Beyotime Biotech (Nanjing, Jiangsu, China); and PVDF membrane from Millipore (NJ, USA). DNA primers were synthesized by Sangon Biotech (Shanghai, China).

The equipment included, fluorescent microscope from Olympus (Japan), $\mathrm{CO}_{2}$ incubator from Heraeus (Germany), FACS Calibur from BD (USA), plate reader from Bio-Tek (USA), 9600 DNA amplifier from PE (USA), Gel Doc 2000 from GE (USA). The millimeter wave signal was generated using the KFA-100A millimeter therapeutics from Beijing Zhongkang Inc. Wavelength range was 7.5-10.0 mm, power density was $4 \mathrm{mw} / \mathrm{cm}^{2}$, radiating area was $33.2 \pm 3 \times 45.6 \pm 4 \mathrm{~mm}$, and the timer was set as $30 \pm 3$ or $60 \pm 6 \mathrm{~min}$.

Animals. Male Sprague-Dawley (SD) rats at 4 weeks of age (total 42) were purchased from the Super-BK Laboratory Animal Inc. (Shanghai, China). Animal handing was strictly according to the institutional guidelines.

Isolation, culture, and identification of rat chondrocytes. Healthy SD rats were sacraficed by cervical dislocation and knee joints were dissected under sterile conditions. Cartilage was cut out, rinsed with PBS containing penicillin and streptomycin 3 times, and washed with DMEM medium 3 times. The cartilage was cut into $1-\mathrm{mm}^{3}$ pieces and incubated in $0.2 \%$ type II collagenase in a flask at $37^{\circ} \mathrm{C}$ and $5 \% \mathrm{CO}_{2}$. Supernatant was collected every $45 \mathrm{~min}$ and spun at $1,000 \mathrm{rpm}$ for $5 \mathrm{~min}$ to collect cell pellet. After 4 cycles of medium change, all cell pellets were resuspended in DMEM complete medium (containing 10\% FBS, $50 \mathrm{mg} / \mathrm{l}$ vitamin C, $100 \mathrm{U} / \mathrm{ml}$ penicillin, and $100 \mathrm{U} / \mathrm{ml}$ streptomycin), filtered through a 200 cell strainer, seeded at $2-3 \times 10^{5} / \mathrm{ml}$, and incubated at $37^{\circ} \mathrm{C}$ with $5 \% \mathrm{CO}_{2}$. These cells were labeled as F0. Medium was changed after $72 \mathrm{~h}$ and then every 3 days thereafter. Cells were observed every day and passaged when they reached $80 \%$ confluency.

The passage 2 chondrocytes were seeded on glass coverslips and incubated for $72 \mathrm{~h}$. Then cells were washed with PBS and fixed in $10 \%$ neutral formaldehyde for $30 \mathrm{~min}$. After treatment with $1 \%$ toluidine blue at room temperature for $30 \mathrm{~min}$, slips were rapidly washed in ethanol, dried, placed on slides, and sealed. Slides were then observed and photos were taken.

Cell treatment and grouping. After the second passage, chondrocytes were seeded at $1 \times 10^{5} / \mathrm{ml}$ in a T-25 flask, cultured for $48 \mathrm{~h}$, and starved in DMEM medium without FBS for $24 \mathrm{~h}$. Cells were then randomly divided into two groups, a millimeter wave treatment group (treated with millimeter wave for 0,15 , 30,60 , or $120 \mathrm{~min}$ ) and a nocodazole group (treated with 0,5 , 25,50 , or $100 \mathrm{nM}$ nocodazole in complete medium for $24 \mathrm{~h}$ ). The detecting head of millimeter wave was hung above the interference cells at a height of $30 \mathrm{~mm}$. All the interference cells were collected in the detecting head-centered circle with a radius of $20 \mathrm{~mm}$, which fell within the radiation area of $33.2 \pm 3 \times 45.6 \pm 4 \mathrm{~mm}$. Cell proliferation after treatment was measured using the MTT assay.

Passage 2 chondrocytes were seeded at $1 \times 10^{5} / \mathrm{ml}$ in a T-25 flask, cultured for $48 \mathrm{~h}$, and starved in DMEM medium without FBS for $24 \mathrm{~h}$. Then cells were randomly divided into four groups: control group, normal culture without treatment; experimental group 1, treated with $50 \mathrm{nM}$ nocodazole for $24 \mathrm{~h}$ and receiving no millimeter wave signal; experimental group 2, receiving no nocodazole treatment and treated with millimeter wave signal for $60 \mathrm{~min}$; and experimental group 3, treated with $50 \mathrm{nM}$ nocodazole for $24 \mathrm{~h}$ and receiving millimeter wave signal for $60 \mathrm{~min}$. After treatment, cell proliferation and apoptosis were detected using an MTT assay and DNA staining followed by FACS. Cells were also processed to measure the mRNA levels of CDK2 and cyclin A by RT-PCR and the protein levels of CDK2 and cyclin A by Western blotting. Finally, the cell structure and function were detected using transmission electron microscopy and safranin $\mathrm{O}$ staining.

MTT assay. Passage 2 chondrocytes were seeded in a 96-well plate at $1 \times 10^{4} / \mathrm{ml}(200 \mu 1$ per well $)$, cultured, and treated with nocodazole and millimeter wave signal. The chondrocytes were then washed with PBS once, and $20 \mu 1$ of a $0.5 \%$ MTT solution was added into each well. After incubation at $37^{\circ} \mathrm{C}$ for $4 \mathrm{~h}$, wells were emptied, supplied with $150 \mu 1$ of DMSO, and shaken for $10 \mathrm{~min}$. The OD570 was analyzed on a plate reader.

Fluorescence activated cell sorting (FACS). FACS was performed according to the manufacturer's instruction. After treating with nocodazole and millimeter wave signal, chondrocytes were trypsinized, washed with PBS, and re-suspended at $1 \times 10^{6} / \mathrm{ml}$. Then cell suspension was incubated with A, B, and $\mathrm{C}$ solutions and run on the FACS Calibur $\left(10^{4}\right.$ cells were counted). After DNA analysis using Mod Fit software, the cell numbers in G0/G1, S, and G2/M phases were obtained. 

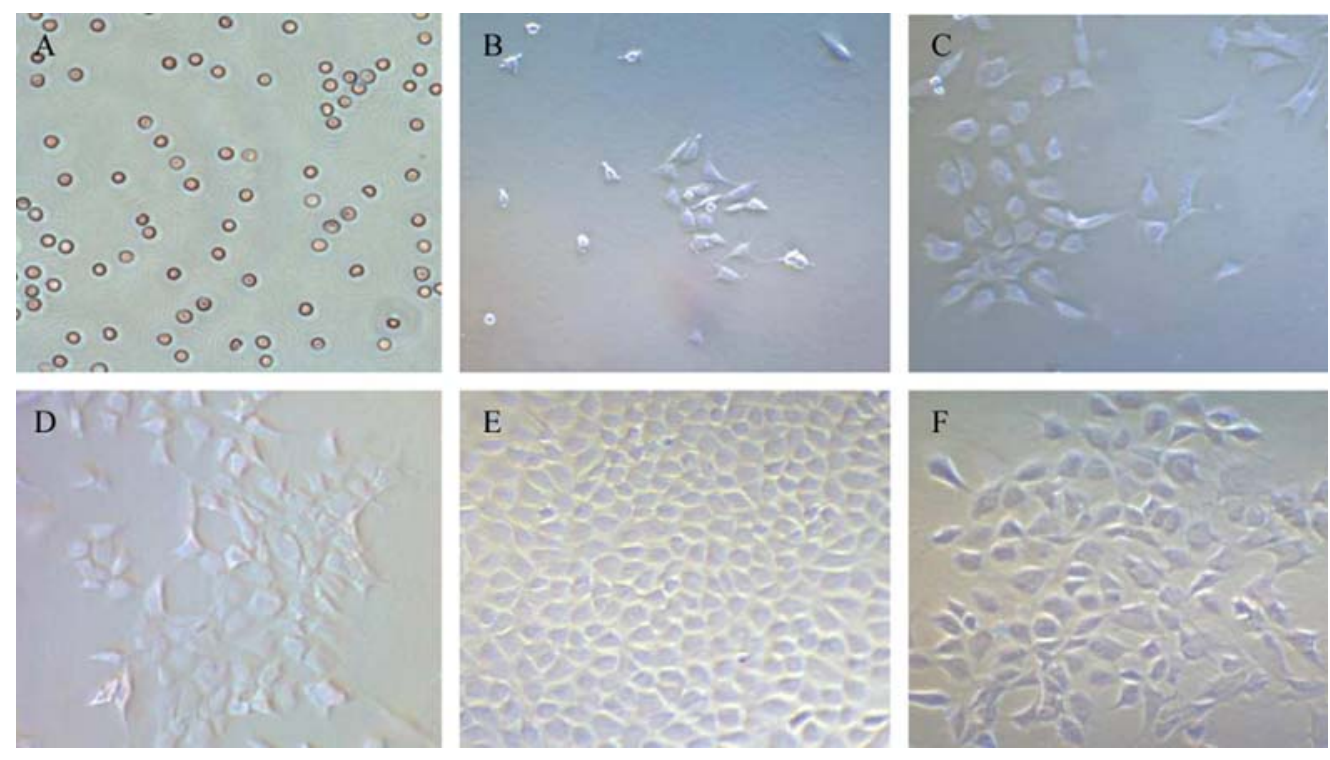

Figure 1. Morphology of primary and passaged chondrocytes (x100). Image of primary cells cultured (A) immediately after seeding, (B) for 24 h, (C) for 3 days, (D) cells cultured for 6 days, (E) 8 days and (F) passage 2 chondrocytes after cultured for 3 days.

$R T-P C R$. Total RNA was extracted from the treated cells using Trizol according to the standard protocol. RNA $(1 \mu \mathrm{g})$ was reverse transcribed into cDNA, which was then used in the PCR amplification of CDK2 (250 bp, sense 5'-AAA GGT GGA GAA GAT TGG-3', antisense 5'-CTT GAG GTC CTG GTG C-3') and cyclin A (210 bp, sense 5'-GCA GCA GAG GCT CAA GAC-3', antisense 5'-GAG ACA GCG GCA CTA AAA-3'). B-actin (385 bp, sense 5'-GGG AAG TGC TGG ATA G-3', antisense 5'-GTG ATG TTT CGG ATG G-3') was used as the internal standard. The PCR conditions were as follows, 1 cycle at $94^{\circ} \mathrm{C}$ for $5 \mathrm{~min}$ and 35 cycles at $94^{\circ} \mathrm{C}$ for $30 \mathrm{sec}, 52 / 53 / 54^{\circ} \mathrm{C}$ for $30 \mathrm{sec}$, and $72^{\circ} \mathrm{C}$ for $30 \mathrm{sec}$. The amplified products were separated on a $1.5 \%$ agarose gel and analyzed. The density of each band was quantified, and the amounts of CDK2 and cyclin A were normalized to B-actin.

Western blotting. After treatment, cells were lysed, and protein concentrations were determined by BCA assay using bovine serum albumin as a standard. Samples were loaded with $20 \mu \mathrm{g}$ of protein and separated by electrophoresis on $12 \%$ SDSpolyacrylamide gels. After electrophoresis, proteins were transferred to PVDF membranes in a Tris-glycine transfer buffer (48 mM Tris, $39 \mathrm{mM}$ glycine, $0.05 \% \mathrm{w} / \mathrm{v}$ SDS, $10 \% \mathrm{v} / \mathrm{v}$ methanol) using a semidry blotting system, detected with antibodies against CDK2, cyclin A, and $B$-actin, and developed with ECL. The intensity of each band was quantified utilizing the Fluor-S gel analyzing system and normalized to the band intensity of $\beta$-actin.

Transmission electron microscopy. After treatment with or without millimeter wave signal, chondrocytes were trypsinized, fixed in $3 \%$ glutaraldehyde $-1.5 \%$ paraformaldehyde for $24 \mathrm{~h}$ at $4{ }^{\circ} \mathrm{C}$, post-fixed in $1 \%$ osmic acid $-1.5 \%$ potassium ferrocyanide for $1.5 \mathrm{~h}$, and washed with PBS for $5 \mathrm{~min}$. Then cells were stained with saturated uranyl acetate in $70 \%$ ethanol, dehydrated by a gradient concentrated ethanol-acetone solution, and embedded in epoxy resin 618. After being sectioned at $80 \mathrm{~nm}$, cells were further stained with uranyl acetate and lead citrate for $5 \mathrm{~min}$ and observed using a Hitachi Hu-12A transmission electron microscope.

Safranin $O$ staining. After treatment, chondrocytes were washed with PBS, fixed in $4 \%$ neutral formaldehyde for $30 \mathrm{~min}$, and stained with $1 \%$ safranin $\mathrm{O}$ solution for $5 \mathrm{~min}$. Then cells were de-colored in $0.1 \%$ acetic acid for several seconds, washed with water, dehydrated using $95 \%$ ethanol, and treated with xylene. After being sealed, slides were observed under the light microscope.

Statistical analysis. Statistical data are expressed as mean \pm SD. Statistical analysis was performed by F test and SNK-q test. Differences were considered statistically significant when $\mathrm{P}<0.05$.

\section{Results}

Morphology and characterization of the rat chondrocytes. Primary chondrocytes were small and sphere-shaped with diffuse distribution in the culture flask just after seeding (Fig. 1A). After $24 \mathrm{~h}$, cells started to adhere and were shaped like a big square with fillopodia (Fig. 1B). After 3 days, cells were sphere or polygonal shape with round or oval nuclei (Fig. 1C). After 6 days, cells gradually became isolated colonies with regular shapes and clear boundaries, and cells were spindle or oval shape (Fig. 1D). After 8 days, chondrocytes dramatically proliferated, and cells were confluent in a single cell layer (Fig. 1E). Passage 2 chondrocytes were regular in shape with even size and proliferated rapidly (Fig. 1F).

To characterize isolated chondrocytes, cells were examined by toluidine blue staining. Stained passage 2 chondrocytes demonstrated red/purple particles in the cytoplasm and dark blue round or oval nuclei (Fig. 2A and B). 

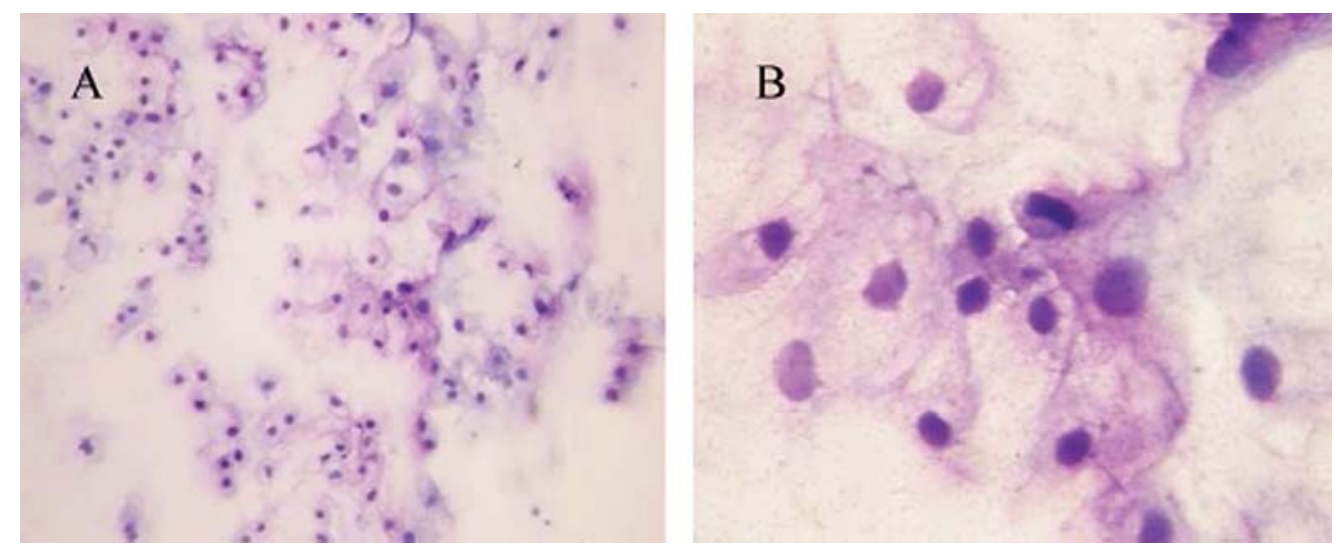

Figure 2. Identification of chondrocytes using toluidine blue staining. (A) Image of passage 2 cells cultured for 3 days and stained using toluidine blue (x100) and (B) image of passage 2 cells cultured for 3 days and stained using toluidine blue (x200).

Table I. Proliferation of chondrocytes measured by MTT.

\begin{tabular}{lcc}
\hline Group & $\begin{array}{c}\text { OD } \\
\text { before treatment }\end{array}$ & $\begin{array}{c}\text { OD } \\
\text { after treatment }\end{array}$ \\
\hline Millimeter wave & & \\
0 min & $0.26 \pm 0.05$ & $0.34 \pm 0.06$ \\
$15 \mathrm{~min}$ & $0.29 \pm 0.06$ & $0.36 \pm 0.04$ \\
$30 \mathrm{~min}$ & $0.27 \pm 0.05$ & $0.39 \pm 0.05$ \\
$60 \mathrm{~min}$ & $0.27 \pm 0.06$ & $0.43 \pm 0.07^{\mathrm{a}, \mathrm{b}}$ \\
$120 \mathrm{~min}$ & $0.28 \pm 0.07$ & $0.44 \pm 0.06^{\mathrm{a}, \mathrm{b}}$ \\
Nocodazole & & \\
$0 \mathrm{nM}$ & $0.25 \pm 0.05$ & $0.37 \pm 0.06$ \\
$5 \mathrm{nM}$ & $0.26 \pm 0.07$ & $0.36 \pm 0.05$ \\
$25 \mathrm{nM}$ & $0.24 \pm 0.06$ & $0.32 \pm 0.06$ \\
$50 \mathrm{nM}$ & $0.27 \pm 0.05$ & $0.28 \pm 0.07^{\mathrm{c}, \mathrm{e}}$ \\
$100 \mathrm{nM}$ & $0.26 \pm 0.04$ & $0.22 \pm 0.05^{\mathrm{c}, \mathrm{d}, \mathrm{f}}$ \\
\hline
\end{tabular}

${ }^{\mathrm{a}} \mathrm{p}<0.01$ compared with millimeter wave $0 \mathrm{~min} ;{ }^{\mathrm{b}} \mathrm{p}<0.05$ compared with millimeter wave $15 \mathrm{~min} ;{ }^{\mathrm{c}} \mathrm{p}<0.01$ compared with nocodazole $0 \mathrm{nM} ;{ }^{\mathrm{d}} \mathrm{p}<0.01$ compared with nocodazole $5 \mathrm{nM} ;{ }^{\mathrm{e}} \mathrm{p}<0.05$ compared with nocodazole $5 \mathrm{nM}$; and ${ }^{\mathrm{f}} \mathrm{p}<0.01$ compared with nocodazole $25 \mathrm{nM}$.

Optimization of millimeter wave treatment time and nocodazole concentration. Without treatment, the passage 2 rat chondrocytes proliferated normally, and there was no significant difference between groups. After treatment with millimeter wave, the ODs of cells receiving 60- and 120-min treatments were significantly higher than the ODs of cells receiving 0 -min $(\mathrm{P}=0.008, \mathrm{P}=0.004)$ and 15 -min treatments $(\mathrm{P}=0.040, \mathrm{P}=0.022)$. The OD of cells treated with $50 \mathrm{nM}$ nocodazole was significantly lower than the ODs of cells treated with $0 \mathrm{nM}$ $(\mathrm{P}=0.009)$ or $5 \mathrm{nM}$ nocodazole $(\mathrm{P}=0.020)$; the $\mathrm{OD}$ of cells treated with $100 \mathrm{nM}$ nocodazole was significantly lower than those of cells treated with $0 \mathrm{nM}(\mathrm{P}=0.000), 5 \mathrm{nM}(\mathrm{P}=0.000)$, or $25 \mathrm{nM}$ nocodazole $(\mathrm{P}=0.006)$ (Table I).

Millimeter wave treatment interfered with nocodazole-induced proliferation inhibition. Next, we tested the effect of the millimeter wave signal on the nocodazole-induced proliferation
Table II. MTT assay results for cell proliferation.

\begin{tabular}{lcccc}
\hline Group & $\begin{array}{c}\text { Noc } \\
(\mathrm{nM})\end{array}$ & $\begin{array}{c}\text { MW } \\
(\mathrm{min})\end{array}$ & $\begin{array}{c}\text { OD } \\
\text { before treatment }\end{array}$ & $\begin{array}{c}\text { OD } \\
\text { after treatment }\end{array}$ \\
\hline Control & 0 & 0 & $0.27 \pm 0.05$ & $0.39 \pm 0.07$ \\
Experimental 1 & 50 & 0 & $0.26 \pm 0.07$ & $0.28 \pm 0.05 \mathrm{a}$ \\
Experimental 2 & 0 & 60 & $0.27 \pm 0.06$ & $0.47 \pm 0.05_{\mathrm{b}, \mathrm{c}}$ \\
Experimental 3 & 50 & 60 & $0.28 \pm 0.06$ & $0.41 \pm 0.06^{\mathrm{c}}$ \\
\hline
\end{tabular}

${ }^{a} \mathrm{p}<0.01$ compared with control group; ${ }^{\mathrm{b}} \mathrm{p}<0.05$ compared with control group; and ${ }^{\mathrm{c}} \mathrm{p}<0.01$ compared with experimental group 1 . Noc, nocodazole.

inhibition by MTT assay. Without treatment, there was no difference between the different groups. After treatment, the OD value of experimental group 1 was significantly lower than those of the control group ( $\mathrm{P}=0.006)$, experimental group 2 $(\mathrm{P}=0.000)$, and experimental group $3(\mathrm{P}=0.001)$. Notably, there were significantly more cells in the experimental group 2 compared with the control group $(\mathrm{P}=0.031)$ (Table II).

Cell cycle distribution of the treated chondrocytes as detected by FACS. Before treatment, all cells were starved for $24 \mathrm{~h}$ to synchronize the cell cycle stage (Fig. 3A-D). The FACS results showed that the cell cycle distribution of cells in different groups were similar. The G0/G1 ratio of experimental group 1 was significantly higher than that of the experimental group 2 ( $\mathrm{P}=0.013)$ following treatment, while the $\mathrm{G} 0 / \mathrm{G} 1$ ratios of experimental groups 2 and 3 were significantly lower than that of the control group $(\mathrm{P}=0.001, \mathrm{P}=0.022)$. The $\mathrm{S}$ ratio of experimental group 1 was significantly lower than the other groups $(\mathrm{P}=0.008, \mathrm{P}=0.000, \mathrm{P}=0.002)$, and the $\mathrm{S}$ ratio of experimental group 2 was significantly higher than those of the control group $(\mathrm{P}=0.004)$ and experimental group 3 $(\mathrm{P}=0.013)$. The $\mathrm{G} 2 / \mathrm{M}$ ratio of experimental group 1 was significantly higher than those of the control group $(\mathrm{P}=0.000)$ and experimental group $2(\mathrm{P}=0.022)$. The $\mathrm{G} 2 / \mathrm{M}$ ratios of experimental groups 2 and 3 were significantly higher than that of the control group $(\mathrm{P}=0.020, \mathrm{P}=0.002)$ (Fig. 3E-H, Table III). 

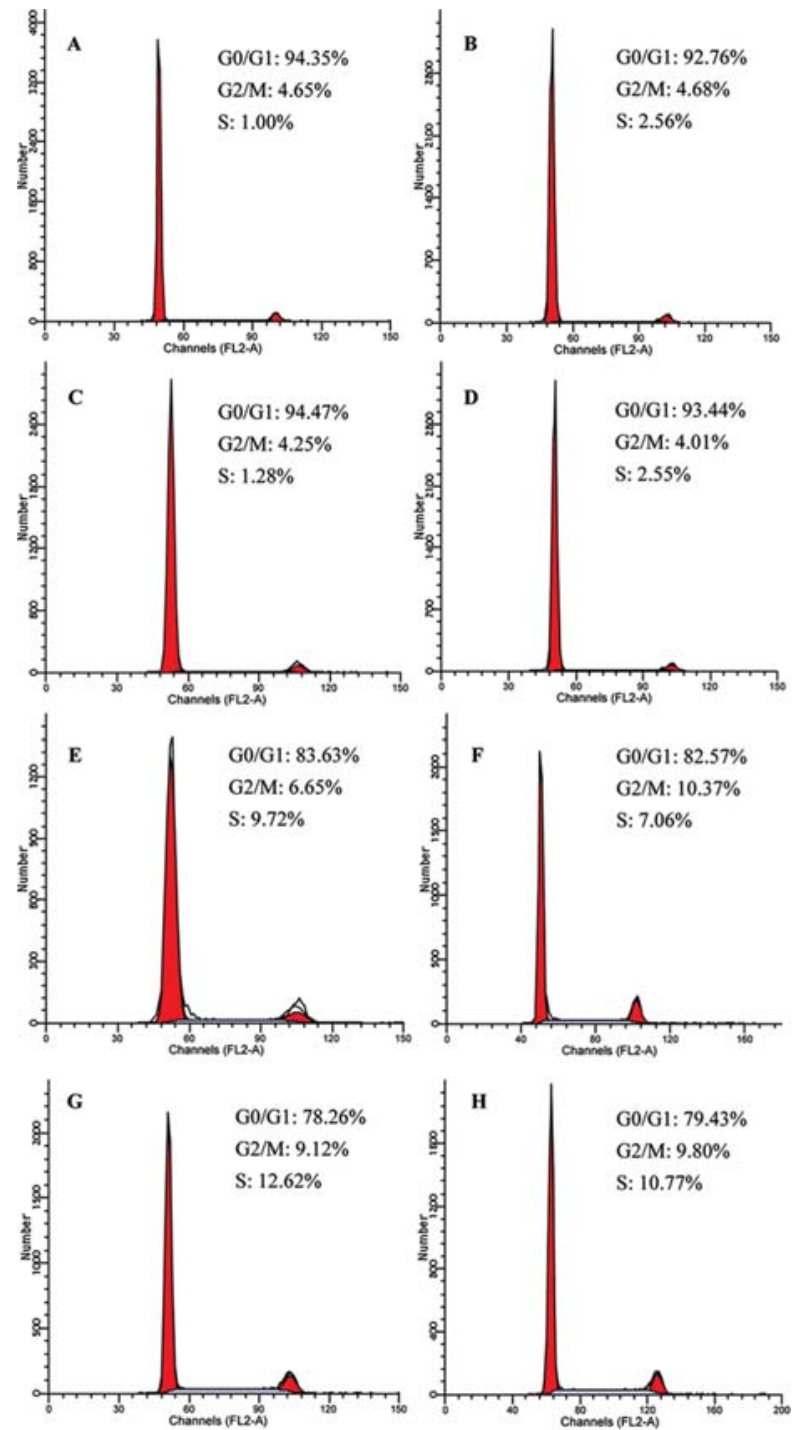

Figure 3. FACS analysis of the chondrocytes with nocodazole treatment and millimeter wave interference. Cells before treatment, (A) control, (B) experimental group 1, (C) experimental group 2 and (D) experimental group 3 cells. Cells after treatment, (E) control, (F) experimental group 1, (G) experimental group 2 and $(\mathrm{H})$ experimental group 3 cells.

Millimeter wave signal regulated the expression of CDK2 and cyclin A. To further explore the mechanism of the millimeter wave signal, we analyzed the expression levels of CDK2 and cyclin A. The mRNA expression of CDK2 and cyclin A was first detected using RT-PCR. The amplified products of $250 \mathrm{bp}$ of CDK2 and 210 bp of cyclin A were clearly visible on the agarose gel (Fig. 4). Quantification of the PCR products indicated that the level of CDK2 was significantly lower in experimental group 1 than in the other groups $(\mathrm{P}=0.007$, $\mathrm{P}=0.000, \mathrm{P}=0.002)$. The CDK2 mRNA level in experimental group 2 was also significantly higher than that of control group $(\mathrm{P}=0.037)$. The levels of cyclin $\mathrm{A}$ in the different groups also showed the same trend as that of CDK2 (Table IV).

The protein expression of CDK2 and cyclin A was also detected using Western blotting. Quantification of the Western blotting bands showed that levels of CDK2 and cyclin A proteins were significantly lower in experimental group 1 than in the other groups $(\mathrm{P}=0.020, \mathrm{P}=0.008 ; \mathrm{P}=0.000, \mathrm{P}=0.000$; $\mathrm{P}=0.004, \mathrm{P}=0.001)$. Protein levels of $\mathrm{CDK} 2$ and cyclin $\mathrm{A}$ in
Table III. Cell cycle distribution detected by FACS (\%).

\begin{tabular}{lccc}
\hline Group & G0/G1 & $\mathrm{S}$ & $\mathrm{G} 2 / \mathrm{M}$ \\
\hline Before treatment & & & \\
Control & $94.12 \pm 2.21$ & $1.85 \pm 0.47$ & $4.03 \pm 1.82$ \\
Experimental 1 & $92.75 \pm 1.71$ & $2.32 \pm 0.72$ & $4.93 \pm 1.04$ \\
Experimental 2 & $94.48 \pm 1.23$ & $1.71 \pm 0.54$ & $3.81 \pm 1.02$ \\
Experimental 3 & $93.17 \pm 1.94$ & $2.28 \pm 0.85$ & $4.55 \pm 1.37$ \\
After treatment & & & \\
Control & $83.40 \pm 2.36$ & $9.91 \pm 1.73$ & $6.69 \pm 1.07$ \\
Experimental 1 & $82.02 \pm 2.14$ & $7.15 \pm 1.18^{\mathrm{a}}$ & $10.83 \pm 1.69^{\mathrm{a}}$ \\
Experimental 2 & $78.25 \pm 3.13^{\mathrm{a}, \mathrm{d}}$ & $12.98 \pm 1.81^{\mathrm{a}, \mathrm{c}}$ & $8.77 \pm 1.70^{\mathrm{b}, \mathrm{d}}$ \\
Experimental 3 & $79.96 \pm 1.74^{\mathrm{b}}$ & $10.43 \pm 1.71^{\mathrm{c}, \mathrm{e}}$ & $9.61 \pm 1.11^{\mathrm{a}}$ \\
\hline
\end{tabular}

${ }^{\mathrm{a}} \mathrm{p}<0.01$ compared with control group; ${ }^{\mathrm{b}} \mathrm{p}<0.05$ compared with control group; ${ }^{\mathrm{c}} \mathrm{p}<0.01$ compared with experimental group $1 ;{ }^{\mathrm{d}} \mathrm{p}<0.05$ compared with experimental group 1 ; and ${ }^{\mathrm{e}} \mathrm{p}<0.05$ compared with experimental group 2 .

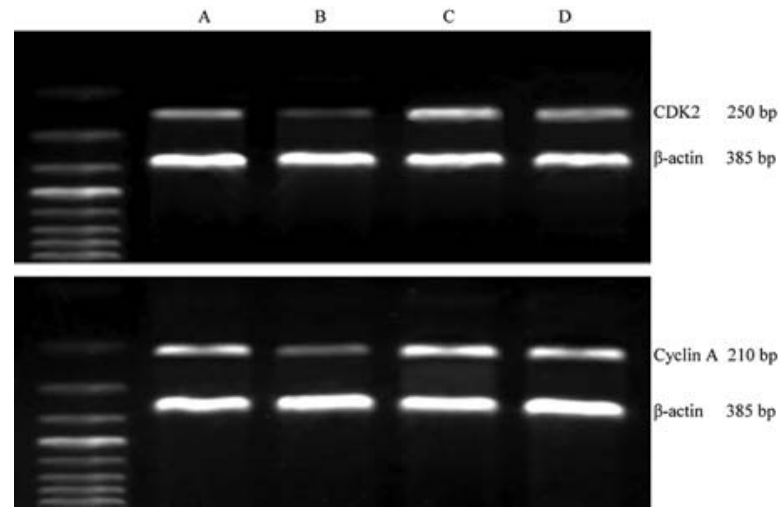

Figure 4. RT-PCR amplification of CDK2 and cyclin A from treated passage 2 chondrocytes. (A) Control, (B) experimental group 1, (C) experimental group 2 and (D) experimental group 3 cells.

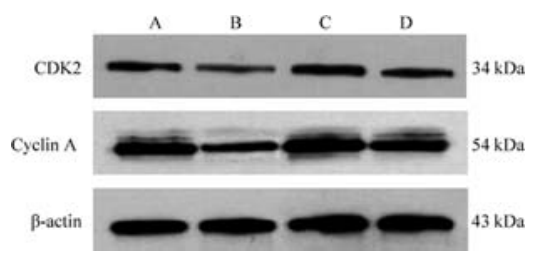

Figure 5. Western blotting of CDK2 and cyclin A from treated passage 2 chondrocytes. (A) Control, (B) experimental group 1, (C) experimental group 2 and (D) experimental group 3 cells.

experimental group 2 were also significantly higher than in the control group ( $\mathrm{P}=0.034, \mathrm{P}=0.020)$ (Fig. 5, Table IV).

Cellular structure by transmission electron microscopy. The shape of cells after treatment were either round, oval, or polygonal. Cell nuclei in the control group and experimental groups 1 and 2 were irregular in shape with lobes, clear nucleoli and evenly distributed chromatin. The rough ER was more abundant in the control group and experimental group 3 cells than in other groups. There were more lysosomes in the experimental group 1 cells. Interestingly, experimental group 2 
Table IV. CDK2 and cyclin A expression in chondrocytes of the different experimental groups.

\begin{tabular}{lllll}
\hline \multirow{2}{*}{ roup } & \multicolumn{2}{c}{ RT-PCR } & \multicolumn{2}{c}{ Western blotting } \\
\cline { 2 - 3 } & CDK2 & Cyclin A & CDK2 & Cyclin A \\
\hline Control & $0.46 \pm 0.05^{\mathrm{b}}$ & $0.54 \pm 0.06^{\mathrm{b}}$ & $0.36 \pm 0.07^{\mathrm{c}}$ & $0.65 \pm 0.06^{\mathrm{b}}$ \\
Experimental 1 & $0.34 \pm 0.07$ & $0.40 \pm 0.05$ & $0.24 \pm 0.08$ & $0.53 \pm 0.08$ \\
Experimental 2 & $0.55 \pm 0.08^{\mathrm{a}, \mathrm{b}}$ & $0.63 \pm 0.08^{\mathrm{a}, \mathrm{b}}$ & $0.46 \pm 0.10^{\mathrm{a}, \mathrm{b}}$ & $0.75 \pm 0.09^{\mathrm{a}, \mathrm{b}}$ \\
Experimental 3 & $0.48 \pm 0.06^{\mathrm{b}}$ & $0.57 \pm 0.06^{\mathrm{b}}$ & $0.38 \pm 0.06^{\mathrm{b}}$ & $0.69 \pm 0.05^{\mathrm{b}}$ \\
\hline
\end{tabular}

${ }^{\mathrm{a}} \mathrm{p}<0.05$ compared with control group; ${ }^{\mathrm{b}} \mathrm{p}<0.01$ compared with experimental group 1 ; and ${ }^{\mathrm{c}} \mathrm{p}<0.05$ compared with experimental group 1.
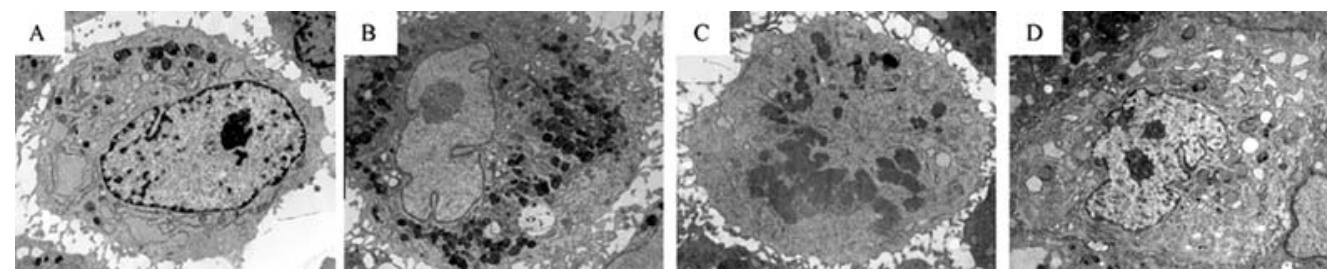

Figure 6. Transmission electron microscopic images of the chondrocytes after treatment (x10,000). (A) Control, (B) experimental group 1, (C) experimental group 2 and (D) experimental group 3 cells.
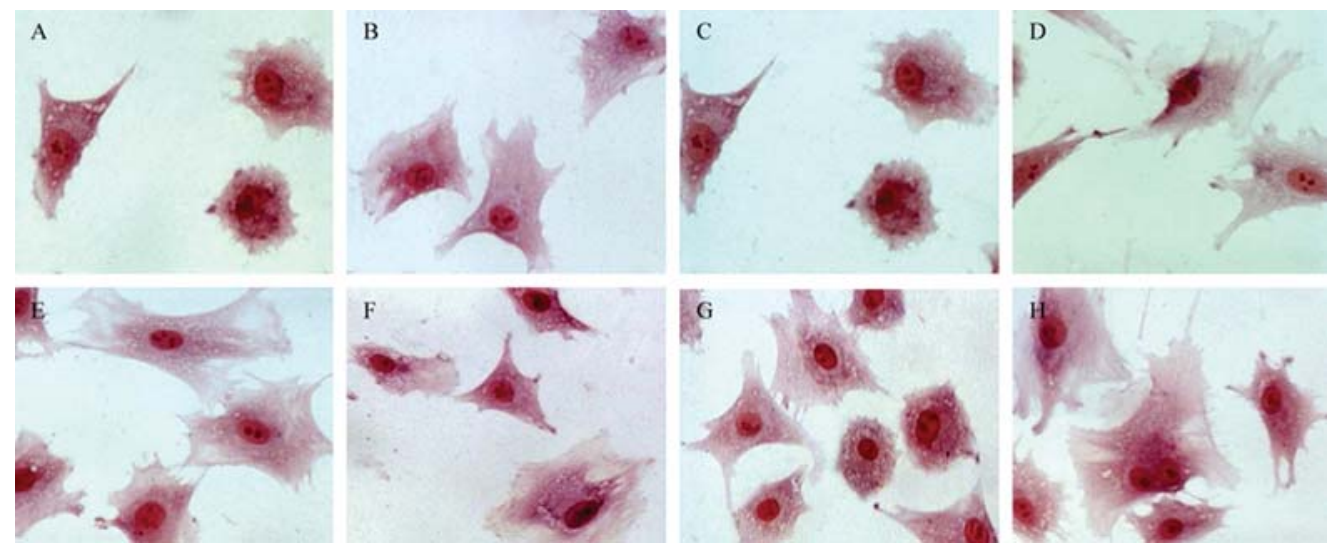

Figure 7. Images of the chondrocytes before and after treatment stained by safranin O (x200). Cells before treatment, (A) control, (B) experimental group 1, (C) experimental group 2 and (D) experimental group 3 cells. Cells after treatment, (E) control, (F) experimental group 1, (G) experimental group 2 and (H) experimental group 3 cells.

cells demonstrated an increase in condensation of the chromosomes and a disappearance of the nuclear membrane, indicating that these cells were in early mitosis (Fig. 6A-D).

Cellular staining by safranin $O$. Before treatment, the chondrocytes were evenly distributed with pink cytoplasm, dark red nuclei, and clear nucleoli (Fig. 7A-D). After treatment, cells showed no dramatic change. However, cells in the control group and in experimental groups 2 and 3 were more condensed than cells in experimental group 1 (Fig. 7E-H).

\section{Discussion}

In our experiments, we employed multiple digestions using $0.2 \%$ type-II collagenase to successfully isolate and in vitro culture rat primary chondrocytes. Primary chondrocytes attach to the bottom of the culture flask slowly, and it usually takes 24-36 h for all cells to attach. Primary chondrocytes also proliferate relatively slowly and usually reach confluence after 7-8 days. After passage, the speed of attachment and proliferation increased. Cells attached to the flask within 6-8 h and reached confluence after 4-5 days. This may be related to the fact that the primary cells were somewhat damaged during the isolation procedure and also the changes in the growth environment. There is no specific marker for chondrocytes. However, proteoglycan secreted by chondrocytes can bind toluidine blue stain through polymer coupling (18). Hence, chondrocytes can be identified by the red-purple staining of toluidine blue.

The frequency of the millimeter wave is in the same range of the frequency $\left(0.5 \times 10^{10}-3 \times 10^{12}\right)$ of coherent oscillation produced by biological organisms during metabolism. 
Therefore, the energy of the millimeter wave can be absorbed by the organism through resonance. In turn, the energy can be transferred to interfere with signal transduction in the organism, dynamically regulating metabolism and promoting cell proliferation. In our study, we showed that millimeter wave treatment efficiently promoted chondrocyte proliferation and the degree of proliferative effect is dependent on the time of millimeter wave treatment. After nocodazole treatment, chondrocyte proliferation was obviously inhibited in a dosedependent manner, although high concentrations of nocodazole did not further increase the inhibition effect, indicating that the inhibitory effect was saturated. After millimeter wave treatment, the inhibitory effect of nocodazole was weakened, suggesting that millimeter wave treatment may function by promoting the G2/M transition of chondrocytes.

There are four stages in the cell cycle, G1, preparing for DNA synthesis; S, DNA synthesis; G2, preparing for mitosis; and $\mathrm{M}$, mitosis (19). The typical time scale is $12 \mathrm{~h}$ for $\mathrm{G} 1,6 \mathrm{~h}$ for $\mathrm{S}, 6 \mathrm{~h}$ for $\mathrm{G} 2$, and $0.5 \mathrm{~h}$ for $\mathrm{M}$ stage. The repeating of this cycle carries out cell proliferation. The amount of DNA in a cell changes during the cell cycle, allowing the different stages of the cycle to be identified by analyzing DNA content. The DNA content is $2 \mathrm{~N}$ in the G0 and G1 cells. After DNA synthesis in $\mathrm{S}$ phase, the DNA content becomes $4 \mathrm{~N}$ in the $\mathrm{G} 2$ and M phases $(20,21)$. FACS analysis, which measures the DNA content of cells, is more sensitive to the changes during the cell cycle than the MTT method. After millimeter wave treatment, the G0/G1 and G2/M ratios dropped, and the $\mathrm{S}$ ratio increased, indicating that millimeter wave treatment promotes cell proliferation by enhancing $\mathrm{S}$ phase entry and accelerating the $\mathrm{G} 2 / \mathrm{M}$ transition. This notion is also supported by our result that after nocodazole treatment the $S$ phase ratio dramatically decreased and the G2/M ratio increased.

Upstream signals are usually transduced by signaling pathways and ultimately function on the genes encoding cell cycle regulating factors, leading to cell cycle changes by altering the expression of these factors. In the process of chondrocyte development, cellular structure and morphology change dramatically under the influence of multiple growth factors and the external environment. Cyclin A is the major regulatory protein in the $S$ phase. Localized mainly in nucleus, cyclin $A$ is expressed at the late G1 stage and functions to promote mitosis $(22,23)$. Cyclin A can bind and activate CDK2, which then initiates the transcription of Sand $M$ phase-related genes, promoting the G2/M transition and thereby cell proliferation. After the late stage of mitosis, cyclin $\mathrm{A}$ is degraded, and the intracellular cyclin A level decreases. Cyclin A is specifically high in $\mathrm{S}$ phase cells, and the protein level of cyclin A may reflect whether the cell population is proliferating. Our results showed that millimeter wave treatment effectively enhanced the mRNA and protein levels of CDK2 and cyclin A. Consistent with these results, FACS analysis showed that the $\mathrm{S}$ ratio increased and the G2/M ratio decreased with treatment. These results suggest that millimeter wave treatment promotes chondrocyte proliferation by accelerating the $\mathrm{G} 2 / \mathrm{M}$ transition.

During the in vitro culture process of chondrocytes, cells may proliferate faster and faster and eventually show structural and functional changes, namely, de-differentiation. In our experiments, there were no significant structural or functional changes of the chondrocytes before and after millimeter wave treatment. After millimeter wave treatment, the chondrocytes proliferated faster and stably expressed and secreted proteoglycan, indicating that millimeter wave treatment promoted chondrocyte proliferation while maintaining the fundamental features of chondrocytes.

In summary, millimeter wave treatment effectively promotes chondrocyte proliferation and also maintains the phenotypic features of chondrocytes. The molecular mechanism of millimeter wave may act by inducing the expression of CDK2 and cyclin $\mathrm{A}$, thereby enhancing $\mathrm{S}$ phase entry, accelerating G2/M transition, and promoting chondrocyte cell cycle progression.

\section{Acknowledgments}

This work was supported by Special Project of Little Invention and Little Creation of Fujian Province (No. 1), the Open Subject of Fujian Key Laboratory of Integrative Medicine on Geriatrics (Grant No. 2008J1004-16).

\section{References}

1. Legendre F, Heuze A, Boukerrouche K, et al: Rhein, the metabolite of diacerhein, reduces the proliferation of osteoarthritic chondrocytes and synoviocytes without inducing apoptosis. Scand J Rheumato 138: 104-111, 2009.

2. Matsumoto T, Cooper GM, Gharaibeh B, et al: Cartilage repair in a rat model of osteoarthritis through intraarticular transplantation of muscle-derived stem cells expressing bone morphogenetic protein 4 and soluble flt-1. Arthritis Rheum 60: 1390-1405, 2009.

3. Guo D, Ding L and Homandberg GA: Telopeptides of type II collagen upregulate proteinases and damage cartilage but are less effective than highly active fibronectin fragments. Inflamm Res 58: 161-169, 2009.

4. Li X, Ellman M, Muddasani P, et al: Prostaglandin E2 and its cognate EP receptors control human adult articular cartilage homeostasis and are linked to the pathophysiology of osteoarthritis. Arthritis Rheum 60: 513-523, 2009.

5. Susaki E, Nakayama K, Yamasaki L, et al: Common and specific roles of the related CDK inhibitors p27 and p57 revealed by a knock-in mouse model. Proc Natl Acad Sci USA 106: 5192-5197, 2009.

6. Cheng $\mathrm{A}$ and Solomon MJ: Speedy/Ringo $\mathrm{C}$ regulates $\mathrm{S}$ and G2 phase progression in human cells. Cell Cycle 7: 3037-3047, 2008.

7. Timofeev O, Cizmecioglu O, Hu E, et al: Human Cdc25A phosphatase has a non-redundant function in $\mathrm{G} 2$ phase by activating cyclin A-dependent kinases. FEBS Lett 583: 841-847, 2009.

8. Joshi AR, Jobanputra V, Lele KM, et al: Distinct properties of cyclin-dependent kinase complexes containing cyclin A1 and cyclin A2. Biochem Biophys Res Commun 378: 595-599, 2009.

9. Saxena UH, Powell CM, Fecko JK, et al: Phosphorylation by cyclin C/cyclin-dependent kinase 2 following mitogenic stimulation of murine fibroblasts inhibits transcriptional activity of LSF during G1 progression. Mol Cell Biol 29: 2335 2345, 2009.

10. Ding H, Han C, Gibson-D'Ambrosio R, et al: Piroxicam selectively inhibits the growth of premalignant and malignant human oral cell lines by limiting their progression through the $\mathrm{S}$ phase and reducing the levels of cyclins and AP-1. Int $\mathrm{J}$ Cancer 107: 830-836, 2003.

11. Millenbaugh NJ, Roth C, Sypniewska R, et al: Gene expression changes in the skin of rats induced by prolonged $35 \mathrm{GHz}$ millimeter-wave exposure. Radiat Res 169: 288-300, 2008.

12. Zhadobov M, Sauleau R, Le Coq L, et al: Low-power millimeter wave radiations do not alter stress-sensitive gene expression of chaperone proteins. Bioelectromagnetics 28: 188-196, 2007.

13. Li XX, Du M, Liu XX, et al: Millimeter wave treatment inhibits NO-induced apoptosis of chondrocytes through the p38MAPK pathway. Int J Mol Med 25: 393-399, 2010. 
14. Wu GW, Liu XX, Wu MX, et al: Experimental study of millimeter wave-induced differentiation of bone marrow mesenchymal stem cells into chondrocytes. Int J Mol Med 23: 461-467, 2009.

15. Hsu SL, Yu CT, Yin SC, et al: Caspase 3, periodically expressed and activated at $\mathrm{G} 2 / \mathrm{M}$ transition, is required for nocodazoleinduced mitotic checkpoint. Apoptosis 11: 765-771, 2006.

16. Song H, Kim SI, Ko MS, et al: Overexpression of DRG2 increases $\mathrm{G} 2 / \mathrm{M}$ phase cells and decreases sensitivity to nocodazole-induced apoptosis. J Biochem 135: 331-335, 2004

17. Ho YS, Duh JS, Jeng JH, et al: Griseofulvin potentiates antitumorigenesis effects of nocodazole through induction of apoptosis and G2/M cell cycle arrest in human colorectal cancer cells. Int J Cancer 91: 393-401, 2001.

18. Karsdal MA, Sumer EU, Wulf H, et al: Induction of increased cAMP levels in articular chondrocytes blocks matrix metalloproteinase-mediated cartilage degradation, but not aggrecanasemediated cartilage degradation. Arthritis Rheum 56: 1549-1558, 2007.
19. Zhang M, Xie R, Hou W, et al: PTHrP prevents chondrocyte premature hypertrophy by inducing cyclin-D1-dependent Runx2 and Runx3 phosphorylation, ubiquitylation and proteasomal degradation. J Cell Sci 122: 1382-1389, 2009.

20. Hwang SG, Song SM, Kim JR, et al: Regulation of type II collagen expression by cyclin-dependent kinase 6 , cyclin D1, and p21 in articular chondrocytes. IUBMB Life 59: 90-98, 2007.

21. Li TF, Chen D, Wu Q, et al: Transforming growth factor-beta stimulates cyclin D1 expression through activation of betacatenin signaling in chondrocytes. J Biol Chem 281: 2129621304, 2006.

22. Li X, Kim JW, Grønborg M, et al: Role of cdk2 in the sequential phosphorylation/activation of C/EBPbeta during adipocyte differentiation. Proc Natl Acad Sci USA 104: 11597-11602, 2007.

23. Sonnenberg-Riethmacher E, Wüstefeld T, Miehe M, et al: Maid (GCIP) is involved in cell cycle control of hepatocytes. Hepatology 45: 404-411, 2007. 